\title{
The potential for constructed wetlands to treat alkaline bauxite residue leachate: Phragmites australis growth
}

\author{
Higgins, D. ${ }^{1,3}$, Curtin, T. ${ }^{2,3}$, Pawlett, $M^{4}$ \& Courtney, R. ${ }^{1,3}$ * \\ ${ }^{1}$ Department of Life Sciences, University of Limerick, Limerick, Ireland. \\ ${ }^{2}$ Department of Chemistry and Environmental Science, University of Limerick, Limerick, \\ Ireland. \\ ${ }^{3}$ Bernal Institute, University of Limerick, Limerick, Ireland. \\ ${ }^{4}$ School of Water Energy and Environment, Cranfield University, Bedfordshire, U.K \\ * ronan.courtney@ul.ie Tel: +35361202427
}

\begin{abstract}
High alkalinity $(\mathrm{pH}>12)$ of bauxite residue leachates presents challenges for the long-term storage and managements of the residue. Recent evidence has highlighted the potential for constructed wetlands to effectively buffer the alkalinity, but there is limited evidence on the potential for wetland plants to establish and grow in soils inundated with residue leachate. A pot based trial was conducted to investigate the potential for Phragmites australis to establish and grow in substrate treated with residue leachate over a $\mathrm{pH}$ range of 8.6-11.1. The trial ran for 3 months, after which plant growth and biomass were determined. Concentrations of soluble and exchangeable trace elements in the soil substrate, and also in the aboveground and belowground biomass were determined. Residue leachate $\mathrm{pH}$ did not affect plant biomass or microbial biomass. With the exception of $\mathrm{Na}$ there was no effect on exchangeable trace elements in the substrate, however increases in soluble metals ( $\mathrm{As}, \mathrm{Cd}, \mathrm{Na}$ ) were observed with increasing leachate concentration. Furthermore, increases in Al, As and V were observed in belowground biomass and for $\mathrm{Cd}$ and $\mathrm{Cr}$ in aboveground biomass. Concentrations within the vegetation biomass were less than critical phytotoxic levels. Results demonstrate the ability for $P$. australis to grow in bauxite residue leachate inundated growth media without adverse effects.
\end{abstract}

Keywords: Hyperalkaline wastes, macrophytes, metal removal, mine water, passive treatment, red mud 


\section{Introduction}

Bauxite residue is the waste by-product generated by the extraction of alumina from bauxite ore via the Bayer Process. The annual global production of bauxite residue is about 120 million tonnes, with an estimated global stockpile of 3 billion tonnes (Klauber et al. 2011). The high alkalinity of bauxite residue presents challenging conditions for the long-term environmental management of bauxite residue disposal areas (BRDAs). Where BRDAs are not managed correctly there is potential for leakage to the surrounding environment representing a high environmental risk (Wang et al. 2015). Requirements for the management and treatment of such drainage waters may persist for many decades following closure (Hua et al. 2015).

Treatment of drainage waters by conventional methods is likely to be expensive, especially if it is to be continued for many decades after closure. Recent research has focused attention on the potential for low-cost, passive technology (constructed wetlands) to treat the alkaline leachates from BRDAs (Hua et al. 2015; Buckley et al. 2016) but the focus of these experiments has been on batch trials at laboratory scale.

Wetlands have been effective in buffering alkaline steel slag leachates (Banks et al. 2006; Mayes et al. 2008) and there is emerging evidence of their ability to treat bauxite residue leachate (Hua et al. 2015; Buckley et al. 2016). The ability of vegetation to establish within the stressful environment of bauxite residue leachate wetlands is unknown. Vegetation of wetlands treating alkaline leachates serve several functions such as flow baffling, provision of a large surface area for inorganic precipitates to be lost from solution, and provision of a continued carbon source for the microbial decomposers responsible for elevating $\mathrm{CO}_{2}$ and thereby the partial pressure of $\mathrm{CO}_{2}\left(\mathrm{pCO}_{2}\right)$ in wetlands (Mayes et al. 2008). Establishment and continued growth of macrophytes is seen as an essential component for an effective wetland system to treat bauxite residue leachates. Potential impacts of alkaline loading on wetland ecosystems include: reduced solubility of micronutrients, reduced microbial activity, reduced availability of potassium and, direct toxicity of the $\mathrm{OH}^{-}$(Mayes et al. 2009).

Alkaline steel slag leachate reduces shoot production, shoot growth and causes higher root:shoot weight ratios in both P. australis and T. latifolia (Lawson 2004). Similarly, Mayes et al. (2009) observed reduced T. latifolia biomass in calcareous substrates receiving 
lime spoil drainage ( $\mathrm{pH}$ up to 12.7). Reduced growth in both of these studies has been attributed to reduced nutrient availability in high $\mathrm{pH}$ substrates (Mayes et al. 2009). Other characteristics that can inhibit vegetation growth in the steel slag wetland environments include low organic matter content, calcareous crusts, poor physical structure and elevated boron (Mayes et al. 2009). Microbial community structure and activity within wetlands play important roles in pollutant removal (Vymazal 2005; Truu et al. 2009). Microbial activity also consumes alkalinity but microbe activity within wetlands is often overlooked in short term laboratory trials (Mayes et al. 2009). The effects of residue leachate loading on soil microbial populations are unknown.

In addition to high alkalinity (ca. pH 13 Buckley et al. 2016) bauxite residue leachates often present high salinity (up to $160 \mathrm{mS} \mathrm{cm}^{-1}$ ) (Mayes et al. 2011). Several oxyanionic forming elements are very soluble at alkaline conditions and high concentrations of $\mathrm{Al}$ (500-1000 mg $\mathrm{L}^{-1}$ ), As (3-5 $\left.\mathrm{mg} \mathrm{L}^{-1}\right)$ and $\mathrm{V}\left(5-10 \mathrm{mg} \mathrm{L}^{-1}\right)$ can occur in the leachate (Burke et al. 2012; Hua et al. 2015). Contamination of soils with "red mud" bauxite residue has resulted in increased levels of trace elements (Rutyers et al. 2011; Lehoux et al. 2013) but there is limited knowledge on the impact of residue leachate to growth media and soils.

For constructed wetlands to be considered as a potential mechanism for buffering bauxite residue derived leachates, the impact of leachate on plant establishment and growth needs to be assessed. We determined whether residue leachate ( $\mathrm{pH}$ range 8.6-11.1) affects Phragmites australis biomass and nutrient uptake in a 10 week pots based experiment. Potential phytoavailability of residue associated trace elements was also assessed by measuring soluble and exchangeable fractions. Substrate microbial biomass was also determined as an indicator of leachate effects on soil microbial properties. 


\section{Materials and methods}

Bauxite residue leachate was collected from an operating residue disposal area, filtered $(0.45$ $\mu \mathrm{m})$ and trace element content determined using a Perkin-Elmer Elan DRCII inductively coupled plasma-mass spectrometer (ICP-MS; As and Cr) and an Optima 5300 DV inductively coupled plasma optical emission spectrometer (ICP-OES; all other elements) (Table 1). Dilutions were prepared in the laboratory representing the anticipated range of closed BRDA leachate (Buckley et al. 2016) (Table 2).

Juvenile Phragmites australis plants were provided by a local nursery and were planted in in $1 \mathrm{~L}$ pots. Growth medium used was a proprietary all-purpose compost ( $\mathrm{pH} 6$, organic content $86 \%$ ), as a previous study by Buckley et al. (2016) demonstrated greater potential for buffering $\mathrm{pH}$ of $\mathrm{NaOH}$ solutions in high organic matter substrates. All plants were pre-grown for one month to acclimatise them to their new environment, which was in a nutrient solution containing: $\mathrm{KNO}_{3}\left(1.5 \mathrm{mmol} \mathrm{L}^{-1}\right), \mathrm{Ca}\left(\mathrm{NO}_{3}\right)_{2}\left(1 \mathrm{mmol} \mathrm{L}{ }^{-1}\right), \mathrm{NH}_{4} \mathrm{H}_{2} \mathrm{PO}_{4}\left(0.5 \mathrm{mmol} \mathrm{L}^{-1}\right)$, $\mathrm{MgSO}_{4} 7 \mathrm{H}_{2} \mathrm{O}\left(0.25 \mathrm{mmol} \mathrm{L}^{-1}\right), \mathrm{KCl}\left(1 \mathrm{mmol} \mathrm{L}^{-1}\right), \mathrm{H}_{3} \mathrm{BO}_{3}\left(25 \mathrm{mmol} \mathrm{L}^{-1}\right), \mathrm{CuSO}_{4} 5 \mathrm{H}_{2} \mathrm{O}(0.1$ mmol L $\left.{ }^{-1}\right),\left(\mathrm{NH}_{4}\right)_{6} \mathrm{Mo}_{7} \mathrm{O}_{24} 4 \mathrm{H}_{2} \mathrm{O}\left(\mathrm{mmol} \mathrm{L}^{-1}\right)$ and $\mathrm{Fe}(\mathrm{Na})$ EDTA $\left(0.1 \mathrm{mmol} \mathrm{L}^{-1}\right)$ (Matthews et al. 2005). Following the acclimatisation period replicate $1 \mathrm{~L}$ pots $(\mathrm{n}=5)$ were placed in basins and subjected to inundation with residue leachate treatments (Table 2). Following the method of Matthews et al. (2005) leachate treatments were fed to the plants at the same volume and on a continuous basis over a 3-month period ensuring the plant pot was submerged in solution at all times.

Measurements of leaf length were carried out weekly and root length was determined at end of experiment. The length of the longest root was measured, by measuring with a ruler from the initial point of growth to the endpoint of the root at the tip. Dry weight measurements of aboveground and belowground biomass were determined at harvest.

Post treatment the wetland plants were carefully removed from the plastic pots to ensure all roots stayed intact. The majority of the compost substrate mass was removed by hand before the roots were washed. Plant material was placed in an oven at $60^{\circ} \mathrm{C}$ for 48 hours. Once dry, the plant aboveground and belowground mass was recorded. Plant samples were acid digested in $\mathrm{HNO}_{3}$ and elemental content determined by ICP (see above). 
Compost substrate samples were split and one half were air-dried prior to physico-chemical analysis. Substrate $\mathrm{pH}$ and EC determined in 1:5 solutions and elemental content was determined in water soluble and exchangeable (1 $\left.\mathrm{M} \mathrm{NH} \mathrm{NH}_{4} \mathrm{OAc}\right)$ extractions. Microbial biomass-C was determined on field fresh $(<2 \mathrm{~mm}$ sieve) substrate using the fumigationextraction procedure (Jenkinson and Powlson 1976) using the correction factor $\mathrm{K}_{\mathrm{EC}}$ of 0.45 (Vance et al. 1987; Joergensen 1996).

Table 1. Selected parameters of bauxite residue leachate

\begin{tabular}{lll}
\hline & This study & Literature values* \\
\hline $\mathrm{pH}$ & 13.2 & $12.6-13.1$ \\
$\mathrm{EC}\left(\mu \mathrm{S} \mathrm{cm}^{-1}\right)$ & 67400 & - \\
$\mathrm{Al}\left(\mu \mathrm{g} \mathrm{l}^{-1}\right)$ & 1077000 & $352000-833500$ \\
$\mathrm{As}\left(\mu \mathrm{g} \mathrm{l}^{-1}\right)$ & 3125 & $6325-8140$ \\
$\mathrm{Cd}\left(\mu \mathrm{g} \mathrm{l}^{-1}\right)$ & 3.2 & - \\
$\mathrm{Cr}\left(\mu \mathrm{g} \mathrm{l}^{-1}\right)$ & 148 & $65-188$ \\
$\mathrm{Ni}\left(\mu \mathrm{g} \mathrm{l}^{-1}\right)$ & 35 & - \\
$\mathrm{V}\left(\mu \mathrm{g} \mathrm{l}^{-1}\right)$ & 13500 & $8977-15600$ \\
\hline
\end{tabular}

*Burke et al. 2012; 2013

Table 2. Dilution rates and $\mathrm{pH}$ of residue leachate treatments

\begin{tabular}{ccr}
\hline Treatment & Dilution & pH \\
\hline Control & - & 6.9 \\
1 & $1: 400$ & 8.5 \\
2 & $1: 300$ & 8.8 \\
3 & $1: 200$ & 9.05 \\
4 & $1: 100$ & 9.9 \\
5 & $1: 75$ & 10.4 \\
6 & $1: 40$ & 11.1 \\
\hline
\end{tabular}


Data were analysed statistically using one-way analysis of variance, descriptive measures and Pearson's bivariate correlations on SPSS, version 19.0. Following the implementation of Kolmogorov-Smirnov one-sample normality tests on SPSS, differences between the residue leachate treatments on substrate and plant properties were individually determined by oneway ANOVA and differences were calculated at the 5\% level using Tukey's test. Figures were constructed using GraphPad Prism, Version 6.

\section{Results}

After the three month growth trial alkaline residue leachate caused a significant increase in substrate $\mathrm{pH}$ that increased with leachate concentration (Fig. 1). At the highest concentration rate of residue leachate (1:40 dilution), $\mathrm{pH}$ increase was $0.6 \mathrm{pH}$ units. Substrate EC increased significantly in all treatments with an EC high of $0.72 \mathrm{mS} \mathrm{cm}{ }^{-1}$ recorded for the highest leachate application rate (3.5* that of the control). Soluble levels of $\mathrm{Mg}$ and $\mathrm{Ca}$ were decreased with increasing application rate of leachate and soluble $\mathrm{Na}$ was increased. Increased soluble As and $\mathrm{Cd}$ was observed with increasing amounts of leachate additions but this increase was only significant for $\mathrm{Cd}$ with the highest leachate $\mathrm{pH}$ loading. With the exception of $\mathrm{Na}$, leachate $\mathrm{pH}$ did not significantly affect exchangeable elements $(\mathrm{Ca}, \mathrm{Mg}, \mathrm{Cr}$, Al) (Table 3). Soluble and exchangeable V was below detection limits. 
Table 3. Ammonium acetate extractable elements $\left(\mathrm{mg} \mathrm{kg}^{-1}\right)$ in bauxite residue leachate treated substrate following Phragmites australis growth trial (means $\pm \mathrm{SE}, \mathrm{n}=5$ )

\begin{tabular}{llllllll}
\hline Treatments & Ca & Mg & Na & Al & As & Ni & Cr \\
\hline Control & $4480 \pm 228 \mathrm{a}$ & $1280 \pm 156 \mathrm{a}$ & $9.5 \pm 3 \mathrm{a}$ & $2.5 \pm 0.1 \mathrm{a}$ & $0.19 \pm 0.02 \mathrm{a}$ & $4.8 \pm 0.7 \mathrm{a}$ & $0.25 \pm 0.01 \mathrm{a}$ \\
pH 8.5 & $3810 \pm 229 \mathrm{a}$ & $1280 \pm 25 \mathrm{a}$ & $93 \pm 7.5 \mathrm{a}$ & $2.4 \pm 0.1 \mathrm{a}$ & $0.35 \pm 0.04 \mathrm{a}$ & $5.0 \pm 0.6 \mathrm{a}$ & $0.26 \pm 0.01 \mathrm{a}$ \\
pH 8.8 & $5300 \pm 122 \mathrm{a}$ & $1830 \pm 76 \mathrm{a}$ & $194 \pm 18 \mathrm{ab}$ & $3.8 \pm 0.7 \mathrm{a}$ & $0.24 \pm 0.02 \mathrm{a}$ & $4.4 \pm 0.1 \mathrm{a}$ & $0.26 \pm 0.01 \mathrm{a}$ \\
pH 9.0 & $4400 \pm 201 \mathrm{a}$ & $1550 \pm 119 \mathrm{a}$ & $243 \pm 33 \mathrm{~b}$ & $2.6 \pm 0.1 \mathrm{a}$ & $0.33 \pm 0.03 \mathrm{a}$ & $4.7 \pm 0.081$ & $0.26 \pm 0.01 \mathrm{a}$ \\
pH 9.9 & $410 \pm 206 \mathrm{a}$ & $1420 \pm 71 \mathrm{a}$ & $461 \pm 55 \mathrm{bc}$ & $2.6 \pm 0.1 \mathrm{a}$ & $0.46 \pm 0.02 \mathrm{a}$ & $4.9 \pm 0.2 \mathrm{a}$ & $0.26 \pm 0.01 \mathrm{a}$ \\
pH 10.4 & $4850 \pm 221 \mathrm{a}$ & $1870 \pm 127 \mathrm{a}$ & $848 \pm 105 \mathrm{c}$ & $3.1 \pm 0.3 \mathrm{a}$ & $0.20 \pm 0.04 \mathrm{a}$ & $5.4 \pm 0.2 \mathrm{a}$ & $0.29 \pm 0.02 \mathrm{a}$ \\
pH 11.3 & $4330 \pm 131 \mathrm{a}$ & $1620 \pm 111 \mathrm{a}$ & $2180 \pm 174 \mathrm{~d}$ & $2.5 \pm 0.1 \mathrm{a}$ & $0.27 \pm 0.03 \mathrm{a}$ & $5.1 \pm 0.1 \mathrm{a}$ & $0.27 \pm 0.01 \mathrm{a}$ \\
\hline
\end{tabular}

Means followed by the same letter in a column are not significantly different at $\mathrm{P} \leq 0.05$

Table 4. Plant growth parameters for Phragmites australis and microbial biomass in substrate samples (means $\pm \mathrm{SE}, \mathrm{n}=5$ )

\begin{tabular}{llllll}
\hline Treatments & $\begin{array}{l}\text { Root } \\
\text { Biomass } \\
(\mathbf{g} / \text { pot) }\end{array}$ & $\begin{array}{l}\text { Root } \\
\text { length } \\
(\mathbf{c m})\end{array}$ & $\begin{array}{l}\text { Shoot } \\
\text { Biomass } \\
(\mathbf{g} / \mathbf{p o t})\end{array}$ & $\begin{array}{l}\text { Shoot } \\
\text { length } \\
(\mathbf{c m})\end{array}$ & $\begin{array}{l}\text { Microbial } \\
\text { biomass } \\
(\boldsymbol{\mu g} \text { C/g) }\end{array}$ \\
\hline Control & $7.6 \pm 1.6 \mathrm{a}$ & $53 \pm 10 \mathrm{a}$ & $1.3 \pm 0.3 \mathrm{a}$ & $56.4 \pm 4.9 \mathrm{a}$ & $780 \pm 152 \mathrm{a}$ \\
pH 8.5 & $5.8 \pm 1.1 \mathrm{a}$ & $43 \pm 7.5 \mathrm{a}$ & $1.2 \pm 0.2 \mathrm{a}$ & $56.5 \pm 9.9 \mathrm{a}$ & $583 \pm 278 \mathrm{a}$ \\
pH 8.8 & $6.5 \pm 1.5 \mathrm{a}$ & $42 \pm 5.7 \mathrm{a}$ & $1.3 \pm 0.2 \mathrm{a}$ & $56.4 \pm 4.8 \mathrm{a}$ & $604 \pm 199 \mathrm{a}$ \\
pH 9.0 & $8.6 \pm 2.6 \mathrm{a}$ & $36 \pm 3.7 \mathrm{a}$ & $2.2 \pm 0.5 \mathrm{a}$ & $74.2 \pm 8.6 \mathrm{a}$ & $460 \pm 376 \mathrm{a}$ \\
pH 9.9 & $8.5 \pm 1.6 \mathrm{a}$ & $38 \pm 5.2 \mathrm{a}$ & $1.9 \pm 0.4 \mathrm{a}$ & $63.5 \pm 6.1 \mathrm{a}$ & $798 \pm 178 \mathrm{a}$ \\
pH 10.4 & $5.7 \pm 1.4 \mathrm{a}$ & $29 \pm 2.3 \mathrm{a}$ & $1.0 \pm 0.3 \mathrm{a}$ & $48.4 \pm 8.1 \mathrm{a}$ & $900 \pm 285 \mathrm{a}$ \\
pH 11.3 & $7.1 \pm 1.0 \mathrm{a}$ & $32 \pm 4.2 \mathrm{a}$ & $1.9 \pm 0.2 \mathrm{a}$ & $68.7 \pm 8.3 \mathrm{a}$ & $516 \pm 145 \mathrm{a}$ \\
\hline
\end{tabular}

Means followed by the same letter in a column are not significantly different at $\mathrm{P} \leq 0.05$

Although decreased root length was observed with increasing concentrations of leachate $\mathrm{pH}$ the difference were not significant (Table 4). There was also no significant differences between treatments for shoot length. Similarly there were no significant differences between treatments for belowground and aboveground biomass. No significant differences were observed for microbial biomass.

There was no significant difference between the treatments for Phragmites australis nutrient content in the belowground samples (Figure 2). Na content significantly increased between each treatment with the highest leachate application displaying results higher than all other treatments but no significant differences were observed for aboveground samples. 
182 For aboveground biomass samples increased leachate $\mathrm{pH}$ did not result in any significant 183 differences for N, K, Na and Mn content (Figure 3). Significantly lower values for Ca, Mg, S 184 and $\mathrm{Mn}$ were observed with increased residue leachate $\mathrm{pH}$.

185 No significant differences were observed for $\mathrm{Ni}, \mathrm{Cd}$ or $\mathrm{Cr}$ content in belowgrond biomass 186 (Figure 4). There was a pattern of increased concentrations with increased rate of leachate 187 for $\mathrm{Al}$, As and $\mathrm{V}$ with significant differences for the higher $\mathrm{pH}$ treatments. Significant 188 differences were also observed for $\mathrm{As}$ and $\mathrm{Al}$ content at the highest application rates. For 189 aboveground samples only $\mathrm{Cd}$ and $\mathrm{Cr}$ displayed significant differences and these were at the 190 higher application rates (Figure 5).

191

192

193

194

195

196

197

198

199

200

201

202

203

204

205

206

207

208

209 
211 Residue leachate was both alkaline and saline with $\mathrm{pH}$ marginally higher than values previously reported (Burke et al. 2012; 2013). Elements determined were also in the range of the previously reported values with the exception of Al which was higher (Burke et al. 2013), possibly due to the slightly higher $\mathrm{pH}$. Whilst there have been no published studies on application of residue leachates to soils and substrates, Lehoux et al. (2013) and Mišík et al. (2014) reported similar findings (increase in $\mathrm{pH}$, increase in salinity and increase in aqueous metal(loid)s concentrations) upon addition of residue to soils.

$\mathrm{Al}$ and $\mathrm{V}$ (except for $\mathrm{pH} 11.1$ ) concentrations in the current study were below the limit of detection, and soluble levels for other elements determined were below values previously reported (Czop et al. 2011; Lehoux et al. 2013) over the same pH range. This may be due to the buffering capacity of the organic substrate used in our study. The most effective soil for buffering residue additions was attributed to those with high organic carbon content (Lehoux et al. 2013; Buckley et al. 2016). Reduction in solution $\mathrm{pH}$ is a critical factor for removing trace elements from alkaline leachate water (Hua et al. 2015).

Adsorption of arsenate and vanadate to mineral surfaces occurs at circumneutral $\mathrm{pH}$ (Peacock and Sherman 2004) and aluminate becomes highly insoluble below about $\mathrm{pH} 10.5$ and precipitates as an amorphous oxyhydroxide phase (Burke et al. 2012). Significant decreases in aqueous $\mathrm{Al}$, As and $\mathrm{V}$ concentrations with red mud additions were observed below approximately $\mathrm{pH} 8.5$ and resulted from an enhancement in both sorption (As and V) and precipitation (Al) that effectively inhibited metal(loid) release to solution (Lehoux et al. 2013). Soluble V in the $\mathrm{pH} 11.1$ treatment was a magnitude of 10 times lower than values reported likely to cause genotoxic effects in plants (Mišík et al. 2014). Although leachate additions in the current study raised substrate $\mathrm{pH}$ levels, all values were considerably lower than $\mathrm{pH}$ 9. Mišík et al. (2014) suggested that $\mathrm{pH}$ control of soil to $\mathrm{pH} 9$ in residue affected soils would mitigate high aqueous concentrations phytotoxic effects.

Increased alkalinity, salinity and sodicity has led to inhibition of root growth in a range of plants growing in bauxite residue aqueous extracts (Courtney and Mullen 2009) and residue additions to soil resulted in decreased plant growth and increased trace element uptake (Ruyters et al. 2011). Decreases in plant growth in alkaline wetland substrates was previously attributed to reduced $\mathrm{N}$ and $\mathrm{P}$ availability in the high $\mathrm{pH}$ substrates (Lawson, 
2004; Mayes et al, 2009). Increased levels of soluble and exchangeable $\mathrm{Na}$ in the compost substrate highlight concern for long-term soil quality and performance in construced wetlands. Soils with high Na content (sodicity) can have reduced permeability and this may impede wetland performance.

Deficiency levels for macronutrients in P. australis of $1.45 \%$ for N, $0.06 \%$ for $\mathrm{P}$ and $0.7-$ $0.75 \%$ for K were reported by Allen and Pearsall (1963). Although leachate additions resulted in a trend of decreased $\mathrm{N}$ content, this was not significantly different and indeed, $\mathrm{N}$ values of $>1.5 \%$ were recorded for the second highest leachate application rate. No treatment displayed nutrient deficiencies in the aerial portions for $\mathrm{P}$ and $\mathrm{K}$. Although significant differences were recorded for $\mathrm{Ca}, \mathrm{Mg}$ and $\mathrm{S}$ content, the $\mathrm{Ca}$ and $\mathrm{Mg}$ content for above ground samples were within the normal range reported by Vymazal and Šveha (2012) for natural wetlands.

Concentrations of $\mathrm{Ca}$ for adequate growth in plants are normally around $0.5 \%$ shoot dry matter (Batty and Younger 2004). For leachate applications of 1:100 this value was not reached. The lower concentrations in the higher $\mathrm{pH}$ loading treatment occurred despite exchangeable reserves for all treatments being adequate although soluble $\mathrm{Ca}$ was significantly decreased. The presence of elevated concentrations of $\mathrm{Na}$ in soluble and exchangeable form may inhibit uptake of $\mathrm{Ca}$ into root tissues. Mean ranges for $\mathrm{Na}$ in belowground tissues in natural wetlands are $0.14-0.27 \%$ and $0.27-0.75 \%$ for constructed wetlands (Vymazal and Šveha 2012). Even with the higher application rates the Na content of belowground samples is at the lower end of the constructed wetlands values. Transfer of $\mathrm{Na}$ into aerial portions as a result of higher leachate loadings was not evident.

Out of 6 non-nutrient elements detected in plant samples, concentrations in belowground biomass were several magnitudes higher than in aboveground for $\mathrm{Al}$, As, and $\mathrm{V}$. A trend of higher content in belowground compared to aboveground was also observed for $\mathrm{Cd}, \mathrm{Cr}$ and Ni. Restriction of translocation to aboveground biomass is believed to be a strategy of metal tolerance and plants can avoid the potential effects of high metal concentrations on the photosynthetic tissue (Bragato et al. 2006).

Bonanno (2011) has proposed P. australis as a potential bioindicator of Al trace content in wetlands. In the current study results showed higher concentrations in belowground samples 
with low mobility through to the aerial portions. This phenomenon is well reported as $\mathrm{Al}$ is immobilized in the roots of metallophytes (e.g. Baker et al. 2000; Vymazal et al. 2009; Bonanno 2011). Vegetation content of $\mathrm{Al}$ has also been shown to be affected by concentrations in water and sediment with lower concentrations for both sediment and plant content reported with distance from influent (Lesage et al. 2007). While additions of residue leachate increased levels of $\mathrm{Al}$ in belowground biomass, all concentrations were below those reported for other constructed wetlands treating domestic waste water (Lesage et al. 2007; Vymazal et al. 2009) and much lower than the 1000-3000 mg kg${ }^{-1}$ phytotoxic levels cited by Kabata-Pendias and Pendias (2001).

Cd content in aboveground biomass recorded was significantly increased with leachate applications but values detected were much lower than values reported for constructed wetlands (Lesage et al. 2007; Vymazal et al. 2007), river areas (Bonanno and Giudice 2010) and are well below the phytotoxic range (5-700 $\mathrm{mg} \mathrm{kg}^{-1}$ ) reported by Chaney (1989).

Leachate additions had no effect on belowground $\mathrm{Cr}$ levels and values are considerably lower than the $15-22 \mathrm{mg} \mathrm{kg}^{-1}$ reported by Lesage et al (2007) for P. australis in a constructed wetland. Leachate additions resulted in increased levels of $\mathrm{Cr}$ in aboveground biomass and fall within the same range reported by Lesage et al. (2007) and are at the lower end of the range reported by Vymazal et al. (2007) for a range of constructed wetlands and natural stands. The toxicity range of $\mathrm{Cr}$ levels is $5-30 \mathrm{mg} \mathrm{kg}^{-1}$ (Kabata-Pendias and Pendias 2001) and all values are well below the threshold.

Bonanno (2011) reported that roots in $P$. australis may have inherent protective mechanisms to prevent $\mathrm{V}$ from penetrating into other organs. Such exclusion mechanisms have been demonstrated in several plant species (e.g. Baker 2000) and Qian et al. (2014) have suggested the limited translocation of $\mathrm{V}$ to plant aerial parts provides a selective advantage during colonization and establishment. Soluble forms of V in sediment appear to be readily taken up by roots and soluble vanadium was below limits of detection in all treatment except treatment 6. Although this treatment yielded the highest V content in belowground samples (ca $5.4 \mathrm{mg}$ $\mathrm{kg}^{-1}$ ) this is less than the values reported by Bonanno (2011) for the riverside P. australis in an urbanised area and is considerably lower than values recorded for brownfield root content in P. australis $\left(200 \mu \mathrm{g} \mathrm{g}^{-1}\right)$. Similarly, the low $\mathrm{V}$ content in aboveground biomass $(<0.26 \mu \mathrm{g}$ $\mathrm{g}^{-1}$ ) are several magnitudes lower than those recorded by Qian et al. (2014). 
304 Whilst Ni levels above $5 \mathrm{mg} \mathrm{kg}^{-1}$ are considered toxic (Allen 1989) by the end of the growing period, leaves can accumulate up to $60 \mathrm{mg} \mathrm{kg}^{-1}$ (Bragato et al. 2006). Concentrations in the current study are at the lower end of the range reported for $P$. australis growing in wetlands range from $0.5-9 \mathrm{mg} \mathrm{kg}^{1}$ (Bonanno and Giudice 2010), $0.6-11 \mathrm{mg} \mathrm{kg}^{-1}$ (Vymazal et al. 2007).

As content in the current study are similar to those reported by Vymazal et al. (2009) for constructed wetlands but are considerably lower than reported by Allende et al. (2014) which examined acidic wastewater. Results are in agreement with Vymazal et al. (2009) and Allende et al. (2014) that roots of $P$. australis have greater As concentration than shoots. Allende et al. (2014) attributed elevated As in wetland plants to the immature state of the wetland system.

Buckley et al. (2015) demonstrated the ability of organic soils to buffer high $\mathrm{pH}$ of $\mathrm{NaOH}$ solutions. Similarly, buffering of high $\mathrm{pH}$ residue leachate allows for such soils to support plant growth and avoid excessive uptake of trace elements. Trace element levels in $P$. australis detected in the current study are lower than levels reported by Ruyters et al. (2011) for plants growing in red mud affected soils. Ruyters et al. (2011) reported that although these trace elements were detected they did not exceed toxic limit and hypothesized $\mathrm{Na}$ as the prime cause which affected plant growth. Although not investigated in the current study, chlorophyll content (indicator of stress) has been found to have correlations with total $\mathrm{N}$ content (Lippert et al. 2001). N content did not significantly vary between treatments or display any negative correlations with trace element uptake.

Factors influencing plant uptake in wetland systems include age of wetland system and period of acclimatization, duration of exposure, the type of vegetation and the type of substrate. Accumulation of $\mathrm{Na}$ and metal(loids) in wetland substrates may be problematic in their long-term application for treating hyperalkaline residue leachates. Analysis of stream sediment samples following the red mud spill at Ajka, Hungary demonstrated that the bulk of trace elements were in forms that were not readily bioavailable (Mayes et al 2011). Further work is recommended to investigate trace element accumulation and potential bioavailability in constructed wetlands treating bauxite residue leachate. 


\section{Conclusions}

338 Growth of Phragmites australis (below and above ground growth and biomass) was not 339 adversely affected in bauxite residue leachate treatments ( $\mathrm{pH}$ 8.5-11.1). Whilst some 340 substrate $\mathrm{pH}, \mathrm{EC}$ and $\mathrm{Na}$ content were increased these were not to levels of concern. A 341 pattern of increased trace element content in vegetation was found with increased leachate 342 rates but no treatments were at levels of concern.

344 Previously, batch trials have shown the potential for wetland mechanisms to decrease $\mathrm{pH}$ and 345 trace element concetrantion in bauxite residue leachate and $\mathrm{NaOH}$ solutions. Plant growth 346 and biological activity are integral components of constructed wetlands treating mine waters.

347 The ability of Phragmites australis to grow in the residue leachate treatments provides strong 348 encouragement for constructed wetland approaches to effectively treat alkaline bauxite 349 residue leachate.

351 Acknowledgements

352 This research was supported by funding from the International Aluminium Institute. 


\section{References}

356 Allen SE, Pearsall W (1963) Leaf analysis and shoot production in Phragmites. Oikos 357 14:176-189.

Allen SE (1989) Chemical Analysis of Ecological Material, 2nd edition. Blackwell Scientific Publications, Oxford, 368 pp.

Allende KL, McCarthy DT, Fletcher TD (2014) The influence of media type on removal of arsenic, iron and boron from acidic wastewater in horizontal flow wetland microcosms planted with Phragmites australis. Chem Eng J 246:217-228

Baker AJ (2000) Metal hyperaccumulator plants: a review of the biological resource for possible exploitation in the phytoremediaton of metal-polluted soils. In: Terry N, Baneulos GS (eds) Phytoremediation of contaminated soil and water. CRC Press, Boca Raton, FL, pp 85-107

Banks MK, Schwab AP, Alleman JE, Hunter JG, Hickey JC (2006) Constructed wetlands for the remediation of blast furnace slag leachates. Indiana: Joint Transportation Research Program.

Batty LC, Younger PL (2004) Growth of Phragmites australis (Cav.) Trin ex. Steudel in mine water treatment wetlands: effects of metal and nutrient uptake. Environ Pollut 132:85-93

Bonanno G (2011) Trace element accumulation and distribution in the organs of Phragmites australis (common reed) and biomonitoring applications. Ecotox Environ Safe 74:1057-1064

Bonanno G, Giudice RL (2010) Heavy metal bioaccumulation by the organs of Phragmites australis (common reed) and their potential use as contamination indicators. Ecol Indic 10:639-645.

Bragato C, Brix H, Malagoli M (2006) Accumulation of nutrients and heavy metals in Phragmites australis (Cav.) Trin. ex Steudel and Bolboschoenus maritimus (L.) Palla in a constructed wetland of the Venice lagoon watershed. Environ Pollut 144:967-975.

Buckley R, Curtin T, Courtney R (2016) The potential for constructed wetlands to treat alkaline bauxite residue leachate: laboratory investigations. Environ Sci Pollut Res 23:1411514122

Burke IT, Mayes WM, Peacock CL, Brown AP, Jarvis AP, Gruiz K (2012) Speciation of arsenic, chromium, and vanadium in red mud samples from the Ajka spill site, Hungary. Environ Sci Technol 46:3085-3092.

386 Burke IT, Peacock CL, Lockwood CL, Stewart DI, Mortimer RJ, Ward MB, Renforth P, 387 Gruiz K, Mayes WM (2013) Behavior of aluminum, arsenic, and vanadium during the 
neutralization of red mud leachate by $\mathrm{HCl}$, gypsum, or seawater. Environ Sci Technol 47:6527-6535.

Chaney RL (1989) Toxic element accumulation in soils and crops: protecting soil fertility and agricultural food chains. In: Bar-Yosef, B., Barrow, N.J., Goldshmid, J. (Eds.), Inorganic Contaminants in the Vadose Zone. Springer-Verlag, Berlin, pp. 140-158.

Courtney R, Mullen G (2009) Use of germination and seedling performance bioassays for assessing revegetation strategies on bauxite residue. Water Air Soil Pollut 197:15-22

Czop M, Motyka J, Sracek O, Szuwarzyński M (2011) Geochemistry of the hyperalkaline Gorka Pit Lake (pH>13) in the Chrzanow region, southern Poland. Water Air Soil Pollut 214:423-434

Hua T, Haynes RJ, Zhou YF, Boullemant A, Chandrawana I (2015) Potential for use of industrial waste materials as filter media for removal of Al, Mo, As, V and Ga from alkaline drainage in constructed wetlands-adsorption studies. Water Res 71:32-41

Jenkinson DS, Powlson DS (1976) The effects of biocidal treatments on metabolism in soil-I. Fumigation with chloroform. Soil Biol Biochem 8:167-177

Joergensen R, Wichern F (2008) Quantitative assessment of the fungal contribution to microbial tissue in soil. Soil Biol Biochem 40:2977 - 2991

Kabata-Pendias A, Pendias H (2001) Trace Element in Soils and Plants, $3^{\text {rd }}$ edn. CRC Press, Boca Raton

Klauber C, Gräfe M, Power G (2011) Bauxite residue issues: II. options for residue utilization. Hydrometallurgy, 108:11-32

Lawson CJ (2004) A Preliminary Analysis into the use of Passive Remediation in Calcareous Alkaline Waters, Unpublished MSc. thesis. University of Newcastle upon Tyne

Lehoux AP, Lockwood CL, Mayes WM, Stewart DI, Mortimer RJ, Gruiz K, Burke IT (2013) Gypsum addition to soils contaminated by red mud: implications for aluminium, arsenic, molybdenum and vanadium solubility. Environ Geochem Health 35:643-656

Lesage E, Rousseau DPL, Meers E, Tack FMG, De Pauw N (2007) Accumulation of metals in a horizontal subsurface flow constructed wetland treating domestic wastewater in Flanders, Belgium. Sci Total Environ 380:102-115

Lippert I, Rolletschek H, Kohl JG (2001) Photosynthetic pigments and efficiencies of two Phragmites australis stands in different nitrogen availabilities. Aquat Bot 69:359-365

Matthews DJ, Moran BM, Otte ML (2005) Screening the wetland plant species Alisma plantago-aquatica, Carex rostrata and Phalaris arundinacea for innate tolerance to zinc and comparison with Eriophorum angustifolium and Festuca rubra Merlin. Environ Pollut134:43351 
423 Mayes WM, Younger PL, Aumônier J (2008) Hydrogeochemistry of alkaline steel slag

424 leachates in the UK. Water Air Soil Pollut 195:35-50

425 Mayes WM, Batty LC, Younger PL, Jarvis AP, Kõiv M, Vohla C, Mander U (2009) Wetland

426 treatment at extremes of $\mathrm{pH}$ : A review. Sci Total Environ 407:3944-3957

427 Mayes WM, Jarvis AP, Burke IT, Walton M, Feigl V, Klebercz O, Gruiz K (2011) Dispersal 428 and attenuation of trace contaminants downstream of the Ajka bauxite residue (red mud) 429 depository failure, Hungary. Environ Sci Technol 45:5147-5155

430 Mišík M, Burke IT, Reismüller M, Pichler C, Rainer B, Mišíková K, Mayes WM, 431 Knasmueller S (2014) Red mud a byproduct of aluminum production contains soluble 432 vanadium that causes genotoxic and cytotoxic effects in higher plants. Sci Total 433 Environ 493:883-890

434 Peacock CL, Sherman DM (2004) Vanadium (V) adsorption onto goethite ( $\alpha-\mathrm{FeOOH})$ at $\mathrm{pH}$ 4351.5 to 12: a surface complexation model based on ab initio molecular geometries and EXAFS 436 spectroscopy. Geochim Cosmochim Acta 68:1723-1733

437 Qian Y, Gallagher FJ, Feng H, Wu M, Zhu Q (2014) Vanadium uptake and translocation in 438 dominant plant species on an urban coastal brownfield site. Sci Total Environ 476:696-704

439 Ruyters S, Mertens J, Vassilieva E, Dehandschutter B, Poffijn A, Smolders E (2011) The red 440 mud accident in Ajka (Hungary): plant toxicity and trace metal bioavailability in red mud 441 contaminated soil. Environ Sci Technol 45:1616-1622

442 Truu M, Juhanson J, Truu J (2009) Microbial biomass, activity and community composition 443 in constructed wetlands. Sci Total Environ 407:3958-3971

444 Vance ED, Brookes PC, Jenkinson DS (1987) An extraction method for measuring soil 445 microbial biomass C. Soil Biol Biochem 19:703-707

446 Vymazal J (2005) Horizontal sub-surface flow and hybrid constructed wetlands systems for 447 wastewater treatment. Ecol Eng 25:478-490

448 Vymazal J, Švehla J, Kröpfelová L, Chrastný V (2007) Trace metals in Phragmites australis 449 and Phalaris arundinacea growing in constructed and natural wetlands. Sci Total Environ $450 \quad 380: 154-162$

451 Vymazal J, Kröpfelová L, Švehla J, Chrastný V, Štíchová J (2009) Trace elements in 452 Phragmites australis growing in constructed wetlands for treatment of municipal wastewater. 453 Ecol Eng 35:303-309

454 Vymazal J, Šveha J (2012) Removal of alkali metals and their sequestration in plants in 455 constructed wetlands treating municipal sewage. Hydrobiologia 692:131-143 
457 Wang X, Zhang Y, Lv F, An Q, Lu R, Hu P, Jiang S (2015) Removal of alkali in the red mud 458 by SO2 and simulated flue gas under mild conditions. Environ Prog Sustain Energy 34:81-87

459

460

461

462

463 
Figure captions

466

467 Figure 1. Substrate $\mathrm{pH}, \mathrm{EC}$ and soluble elements in residue leachate treatments. Means

468 followed by the same letter are not significantly different at $\mathrm{P} \leq 0.05$

469

470 Figure 2. Nutrient and Na content in Phragmites australis belowground biomass. Means

471 followed by the same letter are not significantly different at $\mathrm{P} \leq 0.05$

472

473 Figure 3. Nutrient content with Na in Phragmites australis aboveground biomass. Means

474 followed by the same letter are not significantly different at $\mathrm{P} \leq 0.05$

475

476

Figure 4. Trace element content in Phragmites australis belowground biomass. Means followed by the same letter are not significantly different at $\mathrm{P} \leq 0.05$

478

479

Figure 5. Trace element content in Phragmites australis aboveground biomass. Means

480

followed by the same letter are not significantly different at $\mathrm{P} \leq 0.05$

481

482

483

484

485

486

487

488

489

490

491

492 

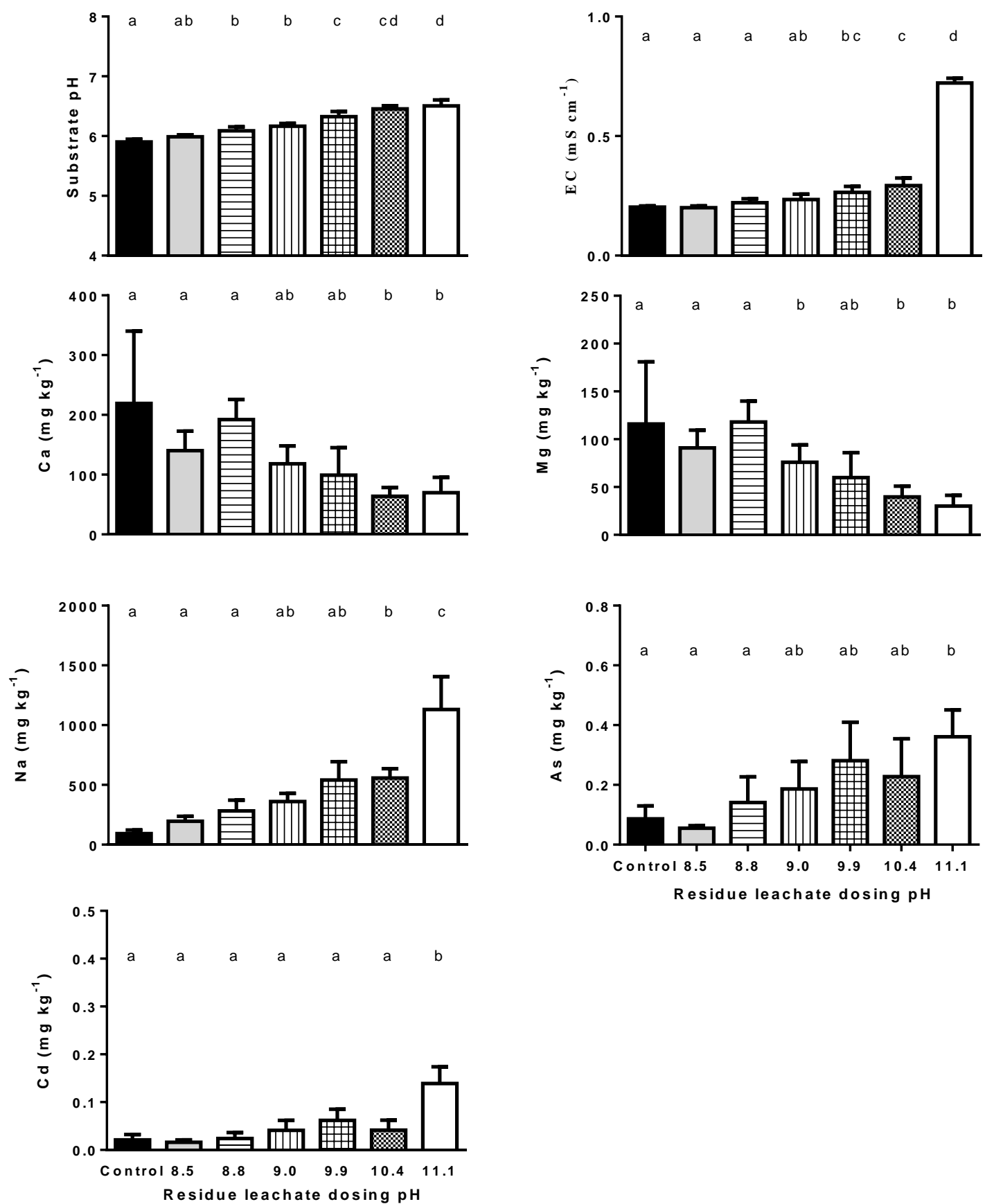

494

495

496

497 
Figure 2
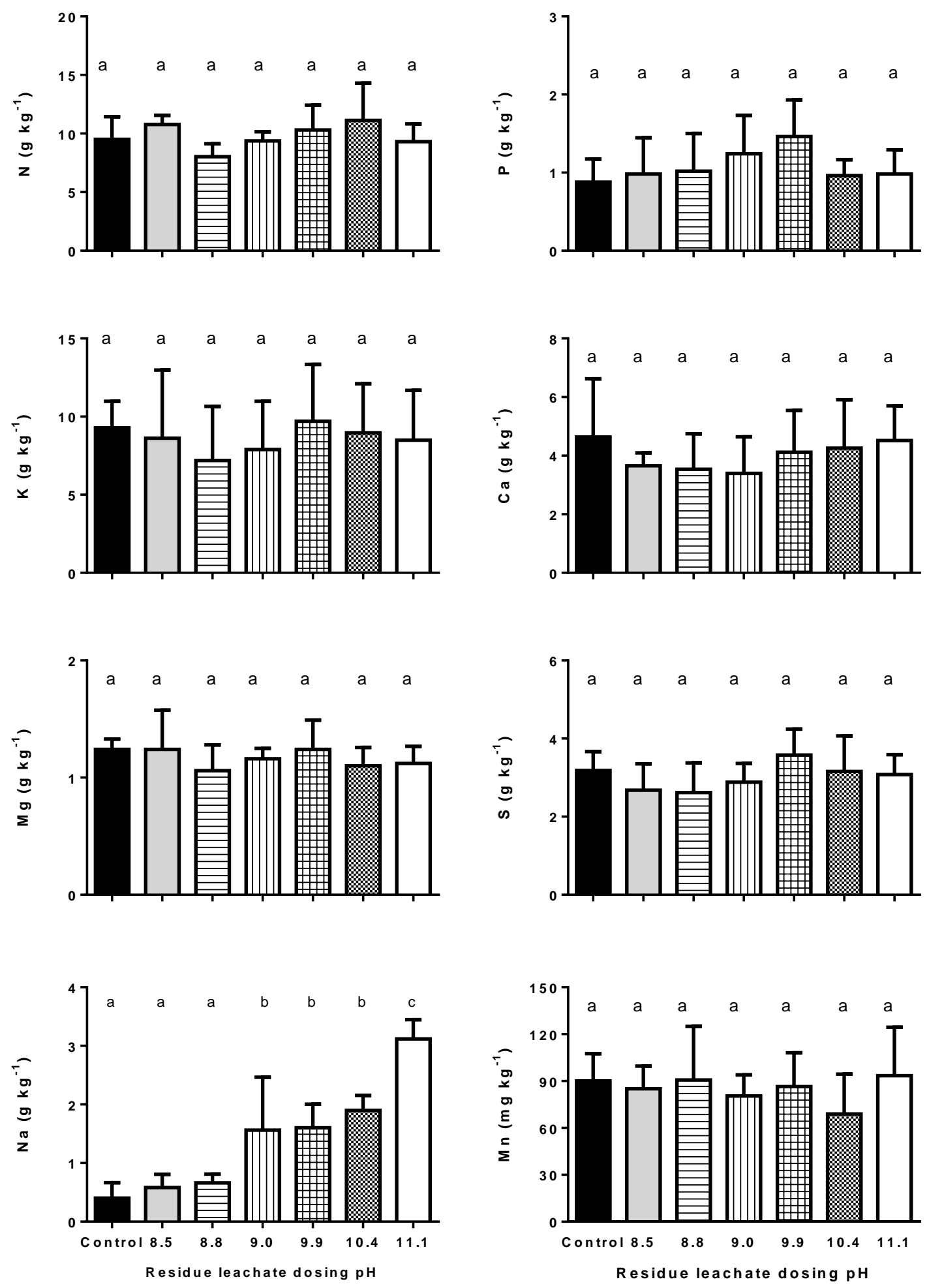
Figure 3
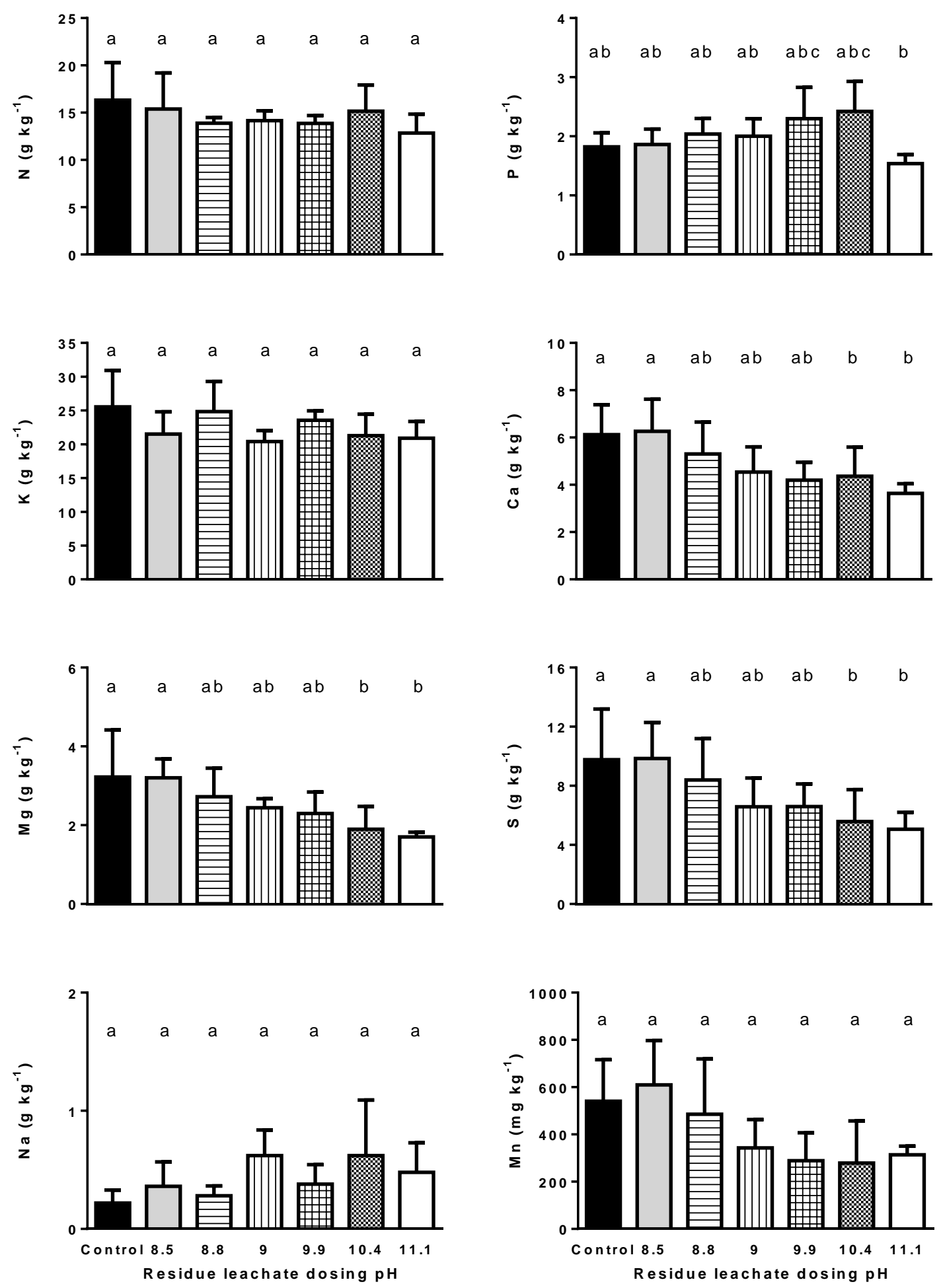

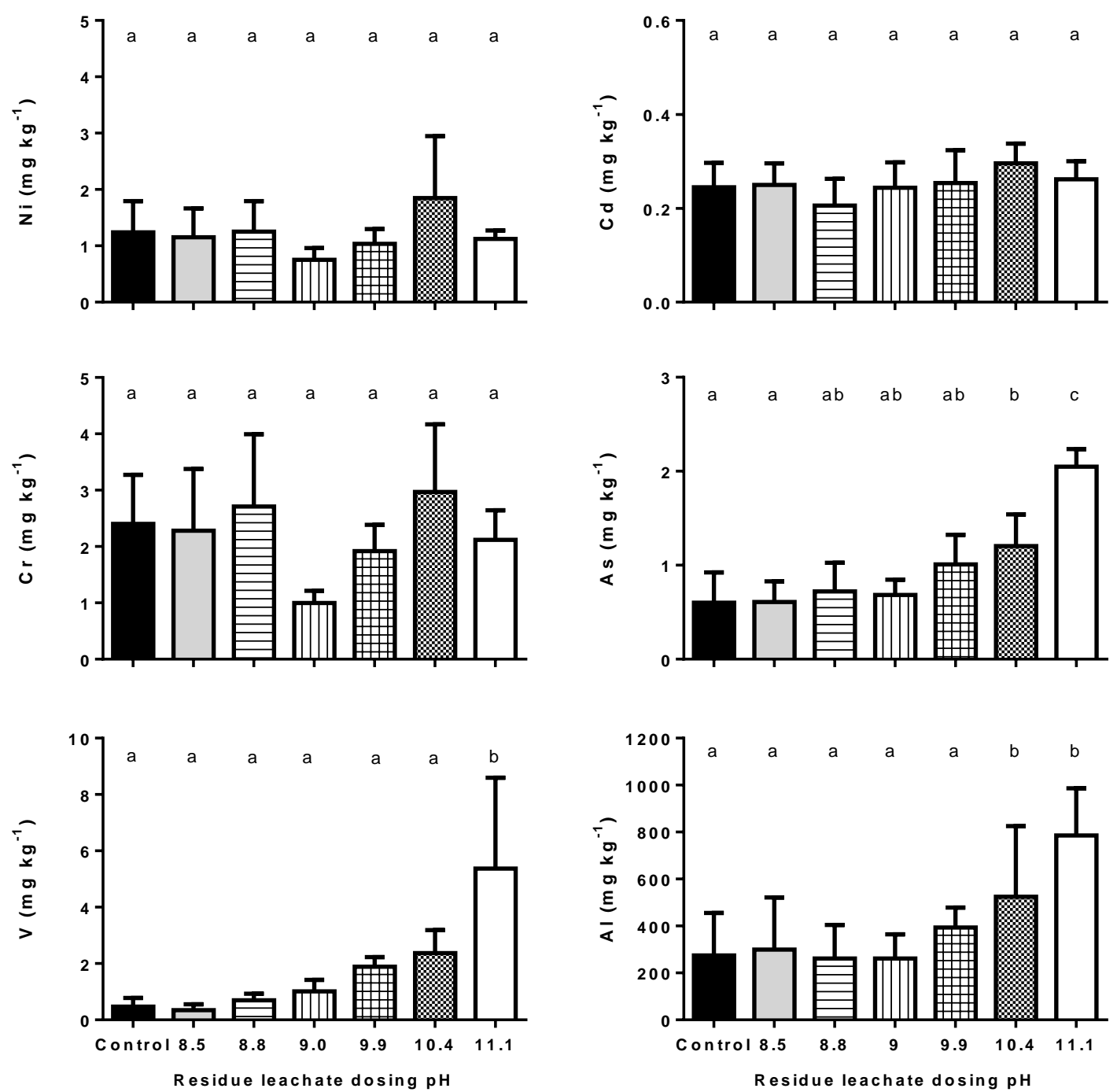
Figure 5
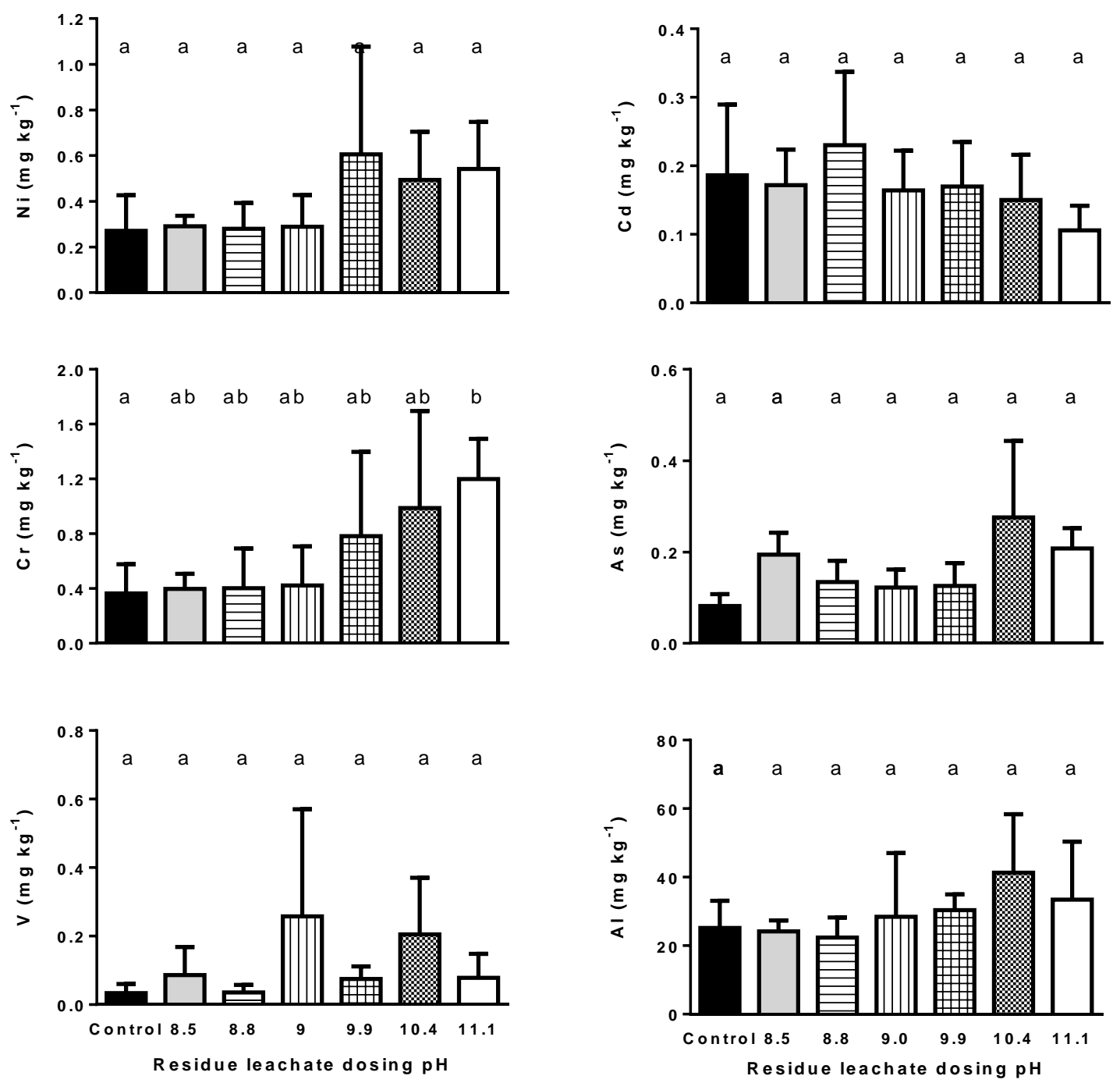

511

512

513

514

515

516

517

518

519 